\title{
NOTES
}

\section{Lack of Deoxyribonucleic Acid-Deoxyribonucleic Acid Homology Between Thermoplasma acidophilum and Sulfolobus acidocaldarius}

\author{
CLAUS CHRISTIANSEN, E. A. FREUNDT, AND O. VINTHER \\ Institute of Medical Microbiology, Bartholin Building, University of Aarhus, DK-8000 Aarhus C Denmark
}

Deoxyribonucleic acids (DNAs) from the type strains of Thermoplasma acidophilum (strain 122-1B2) and Sulfolobus acidocaldarius (strain 98-3) are compared. The guanine-plus-cytosine contents of the DNAs are 45.0 and $39.9 \mathrm{~mol} \%$, respectively. DNA-DNA hybridization experiments show homologies slightly above the background level of $0.1 \%$ in the experiment.

In a previous paper (1) describing the flagellation and swimming motility of Thermoplasma acidophilum, we reviewed and discussed current ideas of the taxonomic position of this organism. As an alternative to the alleged association of this organism with the Mollicutes $(4,8)$, the suggestion was made that it might be regarded as a wall-defective variant (L-phase variant) of a thermophilic and acidophilic bacterium as, for example, Sulfolobus acidocaldarius (2) or the Sulfolobus-like organisms (5). Among the observations that might be adduced in favor of this theory, mention was made of the relatively close values of the guanine-plus-cytosine $(\mathrm{G}+\mathrm{C})$ contents of the deoxyribonucleic acids (DNAs) of $T$. acidophilum and the Sulfolobus-like organisms, viz., $46 \mathrm{~mol} \%(3,7)$ and 39 to $45 \mathrm{~mol} \%$ (5), respectively, although these values are significantly lower than those reported for S. acidocaldarius, viz., 60 to $68 \mathrm{~mol} \%$ (2).

To detect any possible genetic relationship between $T$. acidophilum and the Sulfolobus group, we decided to carry out DNA hybridization experiments with representatives of the two groups of organisms. However, since we were unable to obtain any of the two strains (MT3 and MT4) representing the Sulfolobus-like organisms described by De Rosa et al. (5), we had to attempt hybridization between $T$. acidophilum and S. acidocaldarius. The choice of the latter organism appears to be less logical from its reported high $\mathrm{G}+\mathrm{C}$ content. The strains used were the type strains of each organism: $T$. acidophilum 122-1B2 (ATCC 25905; AMRC-C165) and $S$. acidocaldarius 98-3 (DSM 639) (kindly provided by S. Searcy, Zoology Department, University of Massachusetts, Amherst).
T. acidophilum $122-1 \mathrm{~B} 2$ was grown at $56^{\circ} \mathrm{C}$ in the medium described earlier $(1,3)$, and $S$. acidocaldarius $98-3$ was grown at $75^{\circ} \mathrm{C}$ in the medium described by Langworthy et al. (6), supplemented with sucrose (15 g per liter).

Harvest of organisms, DNA extraction, buoyant density analysis, and DNA-DNA hybridization were performed as described previously (3). Labeling of DNA was done by adding $\left[{ }^{3} \mathrm{H}\right]$ thymidine $(1 \mathrm{mCi} /$ liter) for the last $16 \mathrm{~h}$ of growth. T. acidophilum 122-1B2 labeled well under these conditions, whereas incorporation in the DNA of $S$. acidocaldarius 98-3 did not occur. Therefore, DNA from both strains was labeled with ${ }^{32} \mathrm{P}$ to a specific activity of $4 \times 10^{7} \mathrm{cpm}$ by nick translation (9). The in vivo-labeled DNA from $T$. acidophilum, as well as the in vitrolabeled DNAs, were used in the hybridization experiments.

The $\mathrm{G}+\mathrm{C}$ content of $T$. acidophilum was found to be $45.0 \pm 0.3 \mathrm{~mol} \%$ (mean of three different experiments with standard deviation), thereby confirming the results of earlier studies $(3,7)$. Determination of the $\mathrm{G}+\mathrm{C}$ content of the DNA of strain 98-3 of $S$. acidocaldarius unexpectedly yielded a value of $39.9 \pm 0.3 \mathrm{~mol} \%$ (five experiments). This is, in fact, on line with the values found by De Rosa et al. (5) for their Sulfolobus-like strains MT3 and MT4 and, hence, is highly different from the value of 61 $\mathrm{mol} \%$ reported by Brock et al. for strain 98-3 (2). Since the distinction made by De Rosa et al. (5) between $S$. acidocaldarius and Sulfolobus-like strains was based mainly on the supposed marked difference in $\mathrm{G}+\mathrm{C}$ compositions, it may be concluded from our data that this distinction cannot be maintained. 
The hybridization experiments with standard nitrocellulose filter techniques with hybridization in $2 \times \mathrm{SSC}(0.30 \mathrm{M} \mathrm{NaCl}, 0.03 \mathrm{M}$ trisodium citrate $[\mathrm{pH} 7.0]$ at $65^{\circ} \mathrm{C}$ ) are shown in Table 1 .

The experiment with ${ }^{3} \mathrm{H}$-labeled $T$. acidophilum 122-1B2 DNA gave results identical to those in Table 1. The maximal homology percentage detected in these experiments between DNA from the two strains is $0.25 \%$, barely above the background value for the experiments. Thus, no genetic relationship can be demonstrated between T. acidophilum and S. acidocaldarius by means of DNA-DNA hybridization. This, of course, is not nessarily at variance with the proposed classification of Thermoplasma and Sulfolobus, together with the methanogens and extreme halophiles, in a common phylogenetic group, the Archaebacteria, as based on analyses of their 16S ribosomal RNA sequence homologies $(10,11)$.

TABLE 1. Hybridization experiments with DNA from T. acidophilum 122-1B2 and S. acidocaldarius 98-3

\begin{tabular}{lcccc}
\hline $\begin{array}{c}\text { Source of }{ }^{32} \text { P-la- } \\
\text { beled DNA }\end{array}$ & $\begin{array}{c}\text { Gol\% } \\
\text { DNA } \\
\text { (buoyant } \\
\text { density) }\end{array}$ & $\begin{array}{c}\text { T.aci- } \\
\text { do } \\
\text { philum } \\
122-1 \mathrm{~B} 2^{a}\end{array}$ & $\begin{array}{c}\text { S. aci- } \\
\text { docal- } \\
\text { darius } \\
98-3^{a}\end{array}$ & Blank \\
\hline $\begin{array}{c}\text { T. acidophilum } \\
\text { 122-1B2 }\end{array}$ & 45.0 & 36,595 & 365 & 330 \\
$\begin{array}{l}\text { S. acidocaldar- } \\
\text { ius 98-3 }\end{array}$ & 39.9 & 345 & 42,667 & 244 \\
\hline
\end{tabular}

${ }^{a}$ Each value is the average of four determinations, and the results are given as counts per minute bound per filter.
This research was supported by a grant from the Fogh-Nielsen Foundation.

\section{REPRINT REQUESTS}

Address reprint requests to: Dr. E. A. Freundt, Institute of Medical Microbiology, Bartholin Building, University of Aarhus, DK-8000 Aarhus C, Denmark.

\section{LITERATURE CITED}

1. Black, F. T., E. A. Freundt, O. Vinther, and C. Christiansen. 1979. Flagellation and swimming motility of Thermoplasma acidophilum. J. Bacteriol. 137:456-460.

2. Brock, T. D., K. M. Brock, R. T. Belly, and R. L. Weiss. 1972. Sulfolobus. A new genus of sulfur-oxidizing bacteria living at low $\mathrm{pH}$ and high temperature. Arch. Mikrobiol. 84:54-68.

3. Christiansen, C., E. A. Freundt, and F. T. Black. 1975 Genome size and deoxyribonucleic acid base composition of Thermoplasma acidophilum. Int. J. Syst. Bacteriol. 25:99-101.

4. Darland, G., F. D. Brock, W. Samsonoff, and S. F. Conti. 1970. A thermophilic, acidophilic mycoplasma isolated from a coal refuse pile. Science 170:1416-1418.

5. De Rosa, M., A. Gambacorta, and J. D. Bu'Lock. 1975. Extremely thermophilic acidophilic bacteria convergent with Sulfolobus acidocaldarius. J. Gen. Microbiol. 86: 156-164.

6. Langworthy, T. A., W. R. Mayberry, and P. F. Smith. 1974. Long-chain glycerol diether and polyol dialkyl glycose triether lipids of Sulfolobus acidocaldarius. J. Bacteriol. 119:106-116.

7. Searcy, D. G., and E. K. Doyle. 1975. Characterization of Thermoplasma acidophilum deoxyribonucleic acid. Int. J. Syst. Bacteriol. 25:286-289.

8. Subcommittee on the Taxonomy of Mycoplasmatales. 1974. Minutes of meeting, 5 and 6 September 1973. Int. J. Syst. Bacteriol. 24:390-392.

9. Rigby, P. W. J., M. Dickman, C. Rhodes, and P. Berg. 1977. Labeling deoxyribonucleic acid to high specific activity in vitro by nick translation with DNA polymerase I. J. Mol. Biol. 113:237-251.

10. Woese, C. R., L. J. Magrum, and G. E. Fox. 1978. Archaebacteria. J. Mol. Evol. 11:245-252.

11. Woese, C. R., J. Maniloff, and L. B. Zablen. 1980. Phylogenetic analysis of the mycoplasmas. Proc. Natl. Acad. Sci. U.S.A. 77:494-498. 